\title{
Meat and masculinity in the Norwegian Armed Forces
}

\author{
Charlotte Lilleby Kildal, Karen Lykke Syse @ 2017 \\ Centre for Development and the Environment (SUM), University of Oslo, Pb. 1116 Blindern, \\ 0317 Oslo, Norway
}

\begin{abstract}
In 2013, the Norwegian Armed Forces decided to introduce a meat reduction scheme in its military mess halls, for both health reasons and environmental concerns. This article explores Norwegian soldiers' reactions to the introduction of Meat free Monday, and their attitudes towards reducing meat consumption. As of yet, Meat free Monday has not been implemented due to both structural and contextual challenges. We explore both the process and potential of the Norwegian military's Meat free Monday initiative to promote sustainable and climate friendly diets. We found significant barriers preventing the military from implementing Meat free Monday. The main reason behind the resistance to reduce meat consumption among Norwegian soldiers was meat's associations with protein, masculinity and comfort. Our results underline the importance of acknowledging the social and cultural role of food. The study is qualitative and uses focus group interviews as its main methodology.
\end{abstract}

Keywords: Military; Norwegian Armed Forces; Soldiers’ diets; Meat; Masculinity; Mentality; Sustainable diets;

\section{Introduction}

Meat is frequently addressed in public debates concerning health, food safety, food security, environmental issues and the economy. Studies on meat consumption have predominantly focused on animal welfare, yet recently, meat's association to sustainability, global justice and climate change have become themes for research too. There is a growing awareness about the substantial impact a reduction in meat consumption could have (Garnett, 2011; Gerber et al., 2013; Grønlund, 2015; Westhoek et al., 2014). As much as 30\% of global biodiversity loss and $14.5 \%$ of greenhouse gas emissions stems from animal husbandry (Gerber et al., 2013; Tilman \& Clark, 2014; Westhoek et al., 2014). Furthermore, the production of livestock needs immense land areas, requires large quantities of water, and last but not least animals are fed with grains that could have fed people (Steinfeld et al., 2006; Westhoek et al., 2014). Several authors point to the lack of political action to address the global increase of meat production (Austgulen, 2014; de Boer, Schösler, \& Aiking, 2014; Fuchs \& Lorek, 2005; Spiller \& Nitzko, 2015), although recent exceptions can be mentioned, such as the dietary guidelines in Brazil (Monteiro et al., 2015), Sweden (Friel et al., 2009) and China (Stoll-Kleemann \& Schmidt, 2016).

Even though an increasing body of research concludes that meat consumption ought to decrease for sustainability reasons, few studies take into account how cultural and social dimensions can be an obstacle (Macdiarmid, Douglas, \& Campbell, 2016). There is a need for further interdisciplinary research on the interconnectedness of factors motivating meat consumption and the appropriate strategies to shift diets (Stoll-Kleemann \& Schmidt, 2016).

This study explores a governmental body's attempt to address more sustainable meat consumption, by investigating the process of implementing Meat free Monday (MfM) in the Norwegian Armed Forces. Norwegian public institutions purchase several hundred milliard Norwegian Kroner (NOK) of goods annually (Difi, 2015), and it is essential to understand 
how public spending can be shifted towards sustainability. In addition, the military as a social arena has the potential to influence and educate young people through information, possibly directing their consumption habits towards more sustainable choices. Serving in the Norwegian Armed Forces is compulsory, and from 2016 women were also called in.. About 9,000 of the Armed Forces' personnel employed each year are conscripts, requiring a minimum 12 months service at a military camp. There are three branches, the Army, the Navy and the Air Force. Although National Service is mandatory, service personnel must still meet rigorous physical and psychological criteria, and only $12-13 \%$ are selected (Forsvaret, 2016).

In short, the empirical starting point was the following: In November 2013 the Norwegian Armed Forces announced that they would introduce MfM in all military mess halls by the end of 2014. It was initiated by the Head of Military Catering, who wished to improve both the nutritional value and sustainability of the food served to military personnel. However, several factors made it difficult to implement the MfM initiative. Firstly, organizational and structural factors such as poor communication and decision making: key policy makers in the Armed Forces were reluctant to promote reduced meat consumption as a sustainability measure. The low recognition of the significant environmental benefit of reduced meat consumption is also found in other studies (Bailey, Froggatt, \& Wellesley, 2014; StollKleemann \& Schmidt, 2016; Tobler, Visschers, \& Siegrist, 2011). Secondly, the MfM initiative had been introduced in a top-down manner without informing or involving catering staff. Because of this, MfM was not anchored institutionally. In addition, the main bulk of its kitchen staff wanted to serve the soldiers food they wished to eat, and were concerned that reducing meat would foster negative reactions. As a result, only a minority of the military camps actually introduced any meat reduction measures at all. The assumptions made by the kitchen staff about the soldiers' reluctance to reduce meat consumption were in fact empirically justified (Kildal, 2015).

Understanding this reluctance provides knowledge that is much needed. Other studies confirm an unwillingness to reduce meat consumption (Bohm, Lindblom, Åbacka, Bengs, \& Hörnell, 2015; Graca, Calheiros, \& Oliveira, 2015; Holm \& Møhl, 2000; Makiniemi \& Vainio, 2014; Rothgerber, 2013; Tobler et al., 2011). In a study from Scotland, Macdiarmid et al. (2016) found that the social, personal and cultural values of eating meat were strong barriers against reduction. The Norwegian Armed Forces' effort to reduce meat consumption may serve as a starting point to understand meat consumption among young people more generally, and unveil certain cultural and social barriers towards eating less meat. Why did Norwegian soldiers in our study resist the MfM initiative? We argue that the answer to this can be found in the ideology embedded in the Norwegian Armed Forces alongside the soldier's mentality towards meat consumption, as we will detail further in the following.

\section{Background}

Policies for reducing meat ${ }^{1}$ consumption may face resistance, as meat has high status in many cultures (Fiddes, 1991; Lupton, 1996; Roos \& Wandel, 2004; Rothgerber, 2013). Meat, particularly red meat, is portrayed as the essence of a meal in western countries (Beardsworth \& Bryman, 2004; Fiddes, 1991; Sobal, 2005). Recently meat has also been given an increasingly important role in transition economies such as in India and China (Bailey et al.,

\footnotetext{
${ }^{1}$ This study will not provide a specific definition of meat and vegetarianism. The intention is to map and examine "simply that which people regard as meat", as opposed to providing a moral framework or judgment (Fiddes, 1991, pp. 3-4). Likewise, we do not provide a definition of 'sustainable meat consumption' or 'meateating'. Red meat is however defined as beef, mutton and pork.
} 
2014; Schösler, de Boer, Boersema, \& Aiking, 2015). Meat consumption has increased drastically over the last few decades, and demand for meat is projected to grow by $70 \%$ by 2050 due to global population growth as well as a growing middle-class (Gerber et al., 2013). Globally, meat production has tripled in the past three decades (Pingali \& McCullough, 2010). In Norway, overall meat consumption has continued to rise, from 53 kilos meat per person per year in 1989 to 76 kilos per person in 2015 (The Norwegian Directorate of Health, 2016). The Intergovernmental Panel on Climate Change (IPCC) argues that dietary changes should be part of a transformation towards sustainable consumption (IPCC, 2014), and this was given attention and publicity again at the 2015 United Nations Climate Change Conference, COP21 in Paris, France. However, global political awareness has not resulted in changes in food practices, and factors such as urbanisation, marketing and consumer attitudes continue to drive consumption (Pingali \& McCullough, 2010; Sabaté \& Soret, 2014; Vittersø \& Rosenberg, 2014).

The Norwegian health authorities have also addressed meat consumption levels, recommending Norwegians limit their consumption of red meat to 500g per week. A national survey on Norwegian diets conducted in 2010-11 revealed that the average intake of red meat was $620 \mathrm{~g}$ per week for women, while Norwegian men consumed more than twice the recommended amount, eating 1022g per week (Totland et al., 2012). Only 45\% of Norwegian men and $67 \%$ of Norwegian women consume less than the recommended maximum of $500 \mathrm{~g}$ per week (The Norwegian Directorate of Health, 2016). It is, however, worthwhile noting that in Norway meat consumption is at a substantially lower level than in most other western countries (OECD, 2016), and that in Norway the increase is mainly in poultry consumption (Animalia, 2015).

\subsection{Studying food habits}

By using qualitative methodologies, we describe the underlying mentality of meat consumption in the Norwegian Armed Forces. Williams (1976) defined culture as "the way of life for a whole society". A common anthropological definition of culture is a totality of norms, values and experiences shared by a group of people. This definition of culture coincides well with the term 'mentality' (Löfgren, 1982; Thorsen, 1993). Mentality encapsulates norms, ways of conduct, behaviour-patterns, and perceptions. As the two concepts of culture and mentality in parts overlap, one could argue that it is pointless to differentiate. We use the term culture as Williams does, as it incorporates and envelopes every trait in a society, both material (thus encapsulating food) and immaterial. As such, culture is a concept which is at a different level than mentality and ideas, because it encompasses both. We also choose to differentiate between mentality and ideology. Ideology is explicit, and articulated, while mentality is implicit, and unarticulated. Mentality can be seen as a collective way of thinking which ties a society or culture together, despite individual distinctions (Le Goff, 1980). Mentality is a vague concept, and because of this, it has been considered too unfocused and imprecise to use analytically (Hastrup, 1990; Löfgren, 1987; Setten, 2002; Syse, 2009). Since mentalities are challenging to define, they are also difficult to prove, and like customs, manners and mentalities are transferred unconsciously and without reflection because they are tied to and transmitted by everyday practices which are considered 'right' or 'natural' (Thorsen, 1993). Mentalities refers to collective notions as opposed to more professional and individual constructions of ideas and ideologies (Syse, 2009). The differences between mentality and ideology can be associated with the distinction between the conscious and the unconscious; mentality is tied to social practice and is transmitted unconsciously. Mentalities change very slowly while ideologies change more rapidly (Gullestad, 1986). Although it seems possible to contrast mentality and ideology, the 
boundaries between these two concepts are just as fluid as the boundaries between the conscious and the unconscious (Thorsen, 1993). Yet separating ideology and mentality provides an analytical tool which enables an understanding of the complex set of values the informants hold (Le Goff, Nora, \& Odén, 1978).

Understanding the cultural and social barriers to reducing meat consumption is crucial to enabling change. Both meat as a product and the military as an institution convey the mentality of masculinity, power and strength. Soldiers in our study embrace, embody and consume masculine values through eating meat, and this serves as a symbolic and physical means to maintain masculine ideology. In short, food and meat is a whole lot more than nutrition to the Norwegian soldiers in our study, as we will argue in the following.

\subsection{The cultural role of meat}

Serving and consuming meat has historically symbolised wealth and a higher social class. As with all foodstuffs, meat symbolically includes meanings related to 'goodness' and 'badness', and its high social connotations do not necessarily make its associations all positive (Lupton, 1996). In fact, meat is a clear indicator of food ambivalence, as it is associated with blood and dead flesh as well as power and strength. This contrasting perception of meat causes confusion, something which can be observed through an increase in red meat avoidance among certain groups in society. As Rothgerber notes, "the practice of eating meat has increasingly come under attack" (Rothgerber, 2013, p. 363). While meat traditionally has symbolised strength and power, recent associations with disease, health and food poisoning has led to increased scepticism towards animal products in western diets (Adams, 1990; Fiddes, 1991; Kubberød, Ueland, Tronstad, \& Risvik, 2002; Lavik, 2008; Lupton, 1996). Nevertheless, eating meat has long traditions in Norway, is seen as a central part of the traditional cuisine, and is considered essential for human nutrition and good health (Kubberød, Ueland, Rødbotten, Westad, \& Risvik, 2002; Niva, Mäkelä, Kahma, \& Kjærnes, 2014).

The political and economic incentives for meat production and consumption are strong in Norway. Only 1-2\% of the population state that they are vegetarians; a low number compared to other countries (Lavik, 2008). Consumer research has found that the low number of vegetarians in Norway may be linked to the strong trust in the quality of meat and in the Norwegian food system in general (Guzmán \& Kjærnes, 1998; Kjærnes, Borgen, Borch, \& Lavik, 2010; Lavik, 2008). Lavik found that shifting towards a vegetarian diet seems to be a dramatic step for most Norwegians (Lavik, 2008). Eating is a social practice, and deviating from the norm can be difficult, especially in cultures where meat is central (Bohm et al., 2015; Dagevos \& Voordouw, 2013; Rothgerber, 2013).

\subsection{Meal culture in Norway and in the Armed Forces}

In Norway, dinner is the only warm meal, represents the main meal of the day, and is a social event for the family. 'Traditional' food typically refers to meat and processed meat such as meatballs, or fish served with potatoes and vegetables. Generally, the food served in the Armed Forces is a slightly internationalised version of Norwegian cuisine, with meat or fish dishes as the main component of dinner. Armed Forces personnel eat most of their meals in the mess, although they often have a fast food option in the camp. The majority of the soldiers interviewed for this study ate most of their meals in the mess as it was practical, time-saving and either free (for conscripts) or relatively cheap (for cadets). The mess hall offers three meals a day, normally bread for breakfast, salad-bar and bread for lunch, and a hot meal for dinner. It seemed that lunch was the most popular meal, as the salad-bar gave 
personnel several options and variation of food, such as pasta, pulses, vegetables, chicken and tuna. Norwegian military kitchens serve around 10,000 people each day.

\subsection{Meat and masculinity}

Considerable research has been carried out on food and gender, and results show that women and men think about and relate to food in different ways (Adams, 1990; Bergheim \& Stenberg, 2014; Holm \& Møhl, 2000; Kubberød, Ueland, Rødbotten, et al., 2002; Nath, 2011; Niva et al., 2014; Roos \& Wandel, 2004; Rothgerber, 2013; Schösler et al., 2015). This is based on cultural understandings of differences between women and men (Schösler et al., 2015). The idea that meat is food for men is found in many cultures, from Africa and Southeast Asia, to Europe and North America (Ruby, 2012). Several studies show that men are more likely to emphasise the importance of meat in the diet (Beardsworth et al., 2002; Ruby \& Heine, 2011; Schösler et al., 2015). A survey of Norwegian adults shows a similar pattern (Fagerli \& Wandel, 1999). These studies also found that women are more likely than men to reduce meat consumption. Niva et al. (2014) found that across the Nordic countries, women were more likely to eat sustainably, and young women were particularly concerned about their meat consumption (Kubberød, Ueland, Rødbotten, et al., 2002; Niva et al., 2014).

Meat is not solely a food source for men; it also represents masculine ideology. Adams' (1990) theory on the sexual politics of meat is based on the understanding that meat-eating is linked to masculinity and vegetarianism is linked to feminism. A study found that both vegetarians and meat-eaters rated vegetarians as more virtuous and less masculine than omnivores (Sadalla \& Burroughs, 1981). Meat is a widely established symbol of power, status and masculinity (Ruby \& Heine, 2011; Sobal, 2005). This perspective is essential to this study, as the military is an institution built on masculine values. The connection between meat and the military lies in the masculine ideology connected to both. In times of war, meat has been withheld from civilians to supply fighting men (Kellman, 2000). For example, during the Second World War, the British governments' rationing policies reserved the right to meat for "the epitome of the masculine man: the soldier" (Adams, 1990, p. 32). During war, the meat consumption in the British military was about two and a half times that of the average civilian. Meat was the male prerogative, built on an understanding that by consuming the muscles of strong animals, soldiers will become strong. Even cookbooks for civilians differed from those of soldiers, focusing respectively on complex carbohydrates and variations of meat dishes (Adams, 1990).

Meat is still considered food for 'real men'; a view that is maintained in present day Western culture and that is easy to detect in various media. Heteronormative stereotypes are employed and reinforced by meat advertisements (Rothgerber, 2013). Through TV-commercials meat is presented as man's food. In their analysis of meat in food advertising in Norway Vittersø and Rosenberg demonstrate that very often, men are projected as experts in meat advertisements. Only one of the advertisements analysed in their study showed a female meat expert. The advertisements connect men, butchers, and meat (Vittersø \& Rosenberg, 2014). Celebrity chefs like Jamie Oliver can also be accused of performing heteronormative masculinity and male domination over nature through their TV-shows and books (Parry, 2010; Syse, 2017). The fast food industry and grocery chains build on the same stereotypes with advertisements that focus on meat, barbeques and lifestyle (Vittersø \& Rosenberg, 2014).

Rothgerber (2013) has written extensively on meat-eating and vegetarianism, and in his study on the justification of meat-eating he found that men and women managed the psychological consequences of consuming animals in different ways, and that male strategies to justify meat 
consumption were related to masculinity. The men in the study showed pro-meat attitudes, denied animal suffering, believed that animals are lower in the evolutionary hierarchy than humans, believed that it is a human trait to eat animals and used religious and health justifications. These are classified as direct strategies, while the women in the study used indirect strategies to continue meat-eating, such as denial or 'looking-the-other-way'. According to Rothgerber, the direct justifications are directly related to masculinity, as they convey traditional masculine norms such as stoicism, toughness, emotional restriction and dominance.

Although Norwegian health authorities and environmental experts encourage a decrease in meat consumption, it is not declining. This article acknowledges the challenges underpinned by the social and cultural meanings of meat; its high status and strong symbolic role. In order to facilitate dietary change, policies must take into account the social and cultural factors that influence attitudes towards certain foods and food choice. The military thus represents a good case for studying how the mentality of meat consumption may influence the possibilities of reducing meat consumption and eating vegetarian meals. In the following, we present our data and methods.

\section{Method}

The data analysed in this study was collected through qualitative focus group interviews which took place between September and November 2014. Eleven focus group interviews were conducted at two different military camps, one of them an Army Academy for cadets, Camp 1, the other a camp for conscripts, Camp 2. In total, 61 conscripts and cadets took part in the research, of which 14 were women and 47 men. The focus group interviews lasted from 45 to 90 minutes and each group consisted of three to seven conscripts or cadets (see Table 1). The cadets in Camp 1 were aged between 20-29 years and the conscripts in Camp 2 were aged between 18-22 years. Due to the low number of participants, and easy traceability, the camps and participants will be kept anonymous. We will call representatives from both groups 'soldiers' in the following.

Table 1 Overview of the camps, gender and number of participants in the focus group interviews

\begin{tabular}{lrrr} 
Camp & Male & Female & Total \\
\hline Camp 1 & 24 & 4 & 28 \\
Camp 2 & 23 & 10 & 33 \\
\hline Total & $\mathbf{4 7}$ & $\mathbf{1 4}$ & $\mathbf{6 1}$ \\
\hline
\end{tabular}

Two recruiting methods were used. In Camp 1, a class representative scheduled the interviews, so the cadets were aware of the meeting and the topic to be discussed. This was not the case in Camp 2, where soldiers were asked to volunteer as they entered the mess hall to have dinner. The soldiers were briefed that the topic of the interview was meat and meat reduction. None of the mess halls in these camps had served meat-free meals on a regular basis, and neither of them had implemented MfM. A pilot test was done in Camp 1 while the focus group interviews were conducted. The pilot test was a three week project with meatfree dinners on Thursdays, and information about MfM from the Norwegian NonGovernmental Organisation (NGO), The Future in Our Hands, was posted on the walls of the mess hall. The posters showed emissions from meat production and made comparisons to 
different foods. Since the Armed Forces had not produced any information for their MfM campaign, they had to use NGO material.

The focus group interviews were guided by a set of questions and topics addressed by the interviewer (CK). Normally the interviews followed the same structure: from How and what do you eat in this mess hall?, How did you eat before you joined the military?, Would you say that you are conscious about what you eat, and in what way?, What do you think about eating meat?, What do you think about reducing your own meat consumption?, to What do you know about the connection between food and the environment? The focus group method encouraged a deliberative discussion. In the beginning of our meetings, we sensed scepticism among the soldiers. Several of them gladly volunteered for interviews as they wanted to voice their resistance towards MfM. However, during the focus group interviews, these strong attitudes softened, and the soldiers modified their arguments when they were questioned by their peers. By interacting and challenging each other's arguments, the discussions stimulated deeper reflections on the subject.

The interviewers' role (CK) during the focus group discussions was to moderate the conversation and ask for clarifications when necessary. The interviews were conducted prior to or during a meal, lunch or dinner, in a room next to the mess hall. After each interview observations were noted, and the general atmosphere, setting of the interview and the participants' attitudes were mapped. The interviews were recorded and transcribed, and the data from the interviews was categorised and organised into themes and topics (Malterud, 2001). We organised the data thematically by using colour codes that referred to the different topics (Bertrand, Brown, \& Ward, 1992). The topics the participants emphasised during the interviews were: nutrition, relevance of targeting meat, knowledge, preferences and animal welfare. In this article, we cluster our findings in three main categories: nutrition, masculine ideology and comfort associated with food.

\section{Results}

The pilot test in Camp 1 had prepared the soldiers for the focus group interviews, and triggered a resistance to the MfM project at large. We found a difference between the two camps in which we conducted interviews, as the soldiers from Camp 2, who had not had a similar pilot project, voiced less resistance, although their perceptions of the project and reducing meat consumption were the same.

Armed Forces personnel have jobs that are physically demanding, and therefore food and mealtimes play a significant role, as the following quote ${ }^{2}$ shows:

"Food has a great importance for people in the Armed Forces. For my own part, and people I know, food is one of the most important elements, it is essential for wellbeing.” (Interview 1, Camp 1, Male 23)

\subsection{Nutrition}

Food was defined as nutrition, fuel, building blocks and a physiological necessity. Meat was portrayed as a supreme protein source. Some examples of this can be found below:

"We try to build a robust military, and with the work load and all the exercise that we have, we always try to be at our physical best. How can I get rid of the

\footnotetext{
${ }^{2}$ Please note that all quotes are translated from Norwegian.
} 
fat and build as much muscle as possible? So my focus is: how can I limit eating while maximizing energy input, without gaining fat?” (Interview 1, Camp 1, Male 22)

The majority of soldiers said they were aware of the nutritional value and health benefits of their food choices, and this was their main concern. Sufficient intake of protein was prioritised, and highlighted: "Ensuring enough protein is perhaps my largest concern when eating." one soldier stated (Interview 1, Camp 1, Male 22). Another soldier had a similar comment:

"After I joined the military, and started doing more sports and exercise, I started to think more about what was in the food, (...) when I go to the mess hall, I try to divide it: so I don't eat too many potatoes, not so many carbohydrates, I need more protein, protein is a priority, and then I try to balance it." (Interview 4, Camp 1, Male 21)

Eating muscles in order to build muscles was underlined: "In order to build muscles, you have to eat a lot of meat.” (Interview 2, Camp 1, Male 26)

\subsection{Meat and masculinity}

Most of the soldiers said they respected people that chose not to eat meat; however some of them also referred to this as a "socially challenging diet." ${ }^{3}$ One soldier stated "I don't know any vegetarians myself, but if you're at a dinner party and someone is [a vegetarian], I think, 'weirdo'." (Interview 4, Camp 1, Female 27). This view of the vegetarian as a weirdo was mentioned by many soldiers. Vegetarianism was often referred to as part of animal rights movements, anti-fur demonstrations and moralizing about killing animals. We found that masculine values were used to justify meat-eating and to oppose vegetarianism. Both female and male soldiers projected these masculine values.

"In fact, the Armed Forces is dominated by men, and men are often into meat. We like meat, and because of all the physical pressure, we might want a richer meal.” (Interview 3, Camp 2, Female 20)

Soldiers said that they felt it was unfair and wrong that the need for meat reduction was first addressed in the Armed Forces. To them it seemed like an initiative that would only serve to 'green-wash' the institution.

"It $[\mathrm{MfM}]$ is ironic in an institution that uses tanks, trucks, fighter planes and a bunch of vehicles that have high emissions, and even leave the engine running." (Interview 1, Camp 1, Male 22)

"It's a drop in the ocean considering all the emissions the military is responsible for, and that this might be at the cost of welfare... and that I should get enough nutrition when I'm already struggling with losing [too much] weight when out on exercise.” (Interview 1, Camp 1, Male 23)

Many soldiers did not see reducing meat consumption as the military's responsibility, but rather justified their need for meat. One justification method often used was that meat

\footnotetext{
${ }^{3}$ This was defined as being a difficult guest at dinner parties and was compared to people that have strict lowcarb or gluten-free diets.
} 
consumption is 'normal'. "We are born carnivores, and we have done it [eaten meat] since we were monkeys, so it is completely normal.” (Interview 2, Camp 1, Female 25)

Many female soldiers stated that they felt guilty for not questioning the moral aspects of meat-eating during the focus group interviews. Some of the female soldiers said they felt guilty when they accepted killing and eating animals, and even said they felt they ought to feel worse about it than they actually did. Furthermore, some of the female soldiers questioned the men's endless need for meat during the focus group interviews, and some of them stated that eating huge helpings of meat made them feel heavy and gave them sore stomachs. The majority of the men wanted as much meat as possible.

\subsection{Meat as comfort food}

When the soldiers were asked what kind of meat they preferred, most of them stated that steak, and 'pure' meat was their first choice. They would highlight the physical characteristics of beef, the tenderness and texture of a piece of meat. One soldier claimed that "It is a feeling of mental wellbeing, when you consider the fact that it is pure and delicious meat.” (Interview 5, Camp 2, Male 20)

Food and eating seemed to be important to the soldiers' feelings:

"When there are a lot of exercises, food motivates me, or is like a welfare measure. It must be healthy and taste good, but the pleasure that food gives is just as important as whether it's healthy.” (Interview 1, Camp 1, Male 23)

A recurring theme in the interviews was food as a means of comfort and reward. In every focus group discussion, the need for motivational, tasty and filling food was emphasised. Several of the soldiers said that they were sceptical towards the meat reduction initiative as they were afraid a vegetarian meal would not offer the same comforting feeling as the filling sensation of meat. This is illustrated in the following quotes:

"The challenge with the vegetarian food is that I have to eat twice the amount to cover my needs, if I had a vegetarian dinner, I have to eat another big meal later in the evening." (Interview 1, Camp 1, Male 22)

"There is a difference in the filling feeling after a vegetarian meal and a meal with meat. When I eat salads, I sense that the energy level and filling feeling is not there.” (Interview 2, Camp 1, Male 25)

"The taste of the vegetarian meals was not too bad, but I felt ... where is the meat? Something was missing.” (Interview 1, Camp 1, Male 21)

"I don't know if it is the vitamins or if it is the piece of meat itself, or the stomach that needs something to actually work with. It is impossible to say, but I notice a big difference in my body.” (Interview 2, Camp 1, Male 25)

The soldiers linked the consumption of meat to physical and psychological comfort. Food and eating was portrayed as the highlight of the day, and meat was specifically emphasised in this context.

\section{Discussion}

\subsection{The meaning of eating}


How we eat and respond to food is influenced by cultural and social interaction (Caplan, 1997; Warde, 2016). When the soldiers talked about the meaning of food in their daily routines, they often referred to it as a way of ensuring a fully equipped and prepared body. Soldiers saw meat as the main component of the meal, and thought removing it might result in an insufficient and unsatisfactory meal. Bearing in mind that the initial question explored in this study was not whether or not one ought to consume meat, but identifying the challenges that arise with an initiative that aimed to reduce meat consumption, why was there such reluctance among the participants? Where does the strong need for meat come from and why did the soldiers need so much of it? As we assume the answer to our query "why do we eat so much meat" lies in culturally and socially constructed norms, we will now examine the context in which the soldiers eat. We argue that the way soldiers justify their need for meat is shaped both implicitly, by their mentality and explicitly, through the ideology of the Norwegian Armed Forces, and that this explains the barriers to reduced meat consumption.

\subsection{Meat as protein}

Eating was reduced to a necessary act to ensure energy. The military framing set the meal as a source of physical strength, so the foods' nutritional value was imperative. Their emphasis on nutritional needs can be understood as a way to prepare for unforeseen and physically challenging tasks, which is part of being in the military. Due to the high amount of protein found in meat, its role becomes elevated in the hierarchy of food prioritisation for the soldiers, which reinforces and justifies meat consumption. Fiddes refers to this tendency as "The Protein Myth" in which meat is reduced to protein (Fiddes, 1991). To stay healthy, deal with busy schedules and build muscles, meat had to be on the plate - and in rather substantial amounts - according to the soldiers' point of view. Indeed, most of the soldiers emphasised that animal protein was the most efficient way to procure protein. As the soldiers sought to boost energy and build muscles efficiently, they believed consuming meat was essential.

In other words, meat was projected as the crucial provider of protein and energy and perceived as indispensable to a soldier's diet. This was also demonstrated when soldiers stated that they needed meat to manage physically challenging work. It is not clear, however, whether there is any such physiological need, or whether it is a culturally and socially constructed myth. According to information given by the Norwegian Armed Forces, normal military activity demands about 3,600 calories per day. Exercise at high altitudes and in cold conditions may increase this to about 6,000 calories a day, and prolonged exercises simulating combat may require as many as 10,000 calories per day (Forsvaret, 2013). If the personnel do not get enough calories, then proteins from their own muscles are burnt to produce energy. To maintain body mass and muscle mass, and sufficient energy levels, 1.2-2 grams of protein per kilogram body weight is needed. Consumption of an ordinary mixednutrient diet at these increased energy levels, however, probably usually suffices to meet this need.

Finally, the soldiers did not believe that high meat intake has deleterious health consequences. When confronted with questions about the health implications of meat consumption, such as obesity, diabetes and cancer, the soldiers seemed unaffected. In their opinion, they were in supreme physical condition, lived active lives and, thus, were not at risk for these diseases.

\subsection{Meat as masculine food}

Food consumption is often regarded as a lifestyle choice, and creates social identity (Higgs, 2015). The soldiers interviewed clearly stated that they did not identify with a vegetarian diet. Their image of the vegetarian was associated with something strange and unfamiliar, and 
their initial reaction was to reject the MfM initiative. Most of them regarded vegetarians as outsiders, and believed vegetarian meals were boring, tasteless and unnourishing. They envisioned a meat-free meal as a plate with potatoes, peas and gravy and an empty space where the meat should have been. Studying how people perceive others who follow omnivorous and vegetarian diets and identities, Sadalla and Burroughs found that in general, vegetarians were described as pacifist, weight-conscious and liberal, whereas fast-food lovers were described as patriotic, pro-nuclear, and conservative (Sadalla \& Burroughs, 1981). This might explain, if not confirm our findings. To borrow Mary Douglas's phrase: vegetarianism is considered "matter out of place" in a setting such as the Armed Forces, and thus not immediately considered acceptable (Douglas, 1984). A vegetarian lifestyle was not considered part of the military mentality, as pacifists are not drafted into the Norwegian Armed Forces.

Our focus group interviews showed interesting differences from a quantitative study that was conducted simultaneously, in which a slight variance in attitudes between male and female soldiers was one of the findings (Kildal, 2015). This difference did not surface at all in the focus group interviews, as there was no clear distinction between the opinions of the male and female soldiers. Rather than indicating that women and men have different relations to food, this seemed to demonstrate how masculine mentality and ideology is significant in the military, irrespective of gender. The difference in the findings of the two research methods might be explained through the focus group situation - if there is a dominating masculine mentality in the military, the same might be the case within the focus groups. Were the female soldiers simply adopting these masculine values during interviews due to peer pressure, or at least not contesting them as much as they did in the survey questionnaire? Did the female soldiers want to demonstrate to their peers that they were equally 'competent' as the male soldiers, that they were 'one of the lads'? If so, this might reflect how consuming meat was seen as a power statement, formed by masculine ideology. According to various studies, negative feelings associated with meat are strongest among women (Kubberød, Ueland, Tronstad, et al., 2002; Lavik, 2008; Rothgerber, 2013). Although the female participants in our study did not show negative feelings, they demonstrated more ambivalence in the quantitative study towards the issue than their male colleagues. This indicates that the female soldiers felt they should adhere to stereotypical masculine values in public, yet adhered to stereotypical feminine values in the questionnaire (Kildal, 2015). Although the female soldiers' mentality seemed less meat-focused, they appeared to adopt the predominant masculine ideology.

Focusing on differences between male and female values alone does not fully explain the soldiers' behaviour patterns, however it can demonstrate how the collective masculine values in the military as an institution shape social practice. Stereotypical masculine values, such as men's dominance over nature, were used to justify the need for meat. For example, the soldiers employed an evolutionist argument, stating that humans are carnivorous by nature as they are on top of the food chain. A similar argument was used in several of the focus groups which confirms Rothgerber's theory; that human's indisputable right and power over animals and the natural world is employed as a justification (Rothgerber, 2013). Fiddes claims that this evolutionary justification of meat consumption is a demonstration of power (Fiddes, 1991).

Meat as a symbol of power and virility is interlinked with the stereotypical masculine ideology that dominates the military. When Caplan asks why people eat what they do?, he refers to Bourdieu's concept of distinction. Bourdieu argues that our consumption habits reflect who we are. Consumption becomes a practice of delineation between ourselves and 
other individuals or social groups (Caplan, 1996). When the soldiers emphasise the importance of meat, this confirms their power, strength and masculine identity. Aspects such as strength, security, defence and power are communicated both through the military and through meat. This may imply that reducing intake of meat reduced their masculinity.

Food, and especially the need for meat, played a huge role in the soldiers' lives since it both defined collective notions of who they were as a group and individual ideas about the same. The social and cultural norms dominating the military are barriers to meat reduction because they legitimize meat-eating and simultaneously 'intimidate' the people who depart from the norm (Graca et al., 2015; Stoll-Kleemann \& Schmidt, 2016). In order to overcome the barriers discussed here, a meat reduction scheme such as the MfM would need to be translated into a language and fit an ideology that the soldiers relate to. As Stoll-Kleemann and Schmidt argue, the promotion of new collective norms can be achieved through role models and social marketing. In the military, the hierarchy could be suitable for this, as personnel look up to senior staff.

\subsection{Meat as comfort food}

The soldiers described their daily food intake as 'welfare'. To a large extent, food meant welfare and wellbeing. With a busy schedule and physically demanding days, 'food breaks' encourage and motivate perseverance. Having a warm meal after strenuous exercise or after many hours outside in the cold, was a motivation and reward, and explained why many soldiers did not want meat-free food in the mess hall. To most soldiers, meals were the highlights of the day. Consequently, the soldiers were concerned that reducing their meat consumption would decrease the quality of the food and make it less appetising; and as a result diminish the quality of their most important welfare offer.

When presented with vegetarian dishes, some of the soldiers said they missed the comforting feeling of being full. Furthermore, they showed concern for how the lack of the comfortable bodily experience would reduce their energy levels and motivation during field exercises. Elaborating on that theme, one male soldier argued that the meals work as a motivation, and that this effect is challenged if he has to eat three helpings to feel full. Feeling full after a meal was more important than following a healthy diet. Wallenborn and Wilhite draw on theories by Bourdieu and Mauss when they advocate the importance of bringing "the body back to consumption" (2014, p. 56). They argue that experience, rather than reflexivity, in addition to several other factors such as culture and habits, drive our consumption patterns. This was demonstrated in the case of the soldier's 'need' for meat every day, as their bodily experiences informed their behaviour patterns. The lack of fullness they felt after the vegetarian meals justified their unwillingness to reduce meat consumption. Stress and demanding exercises can also disrupt 'normal' eating patterns, and cause an increase in consumption of fat and salty or sweet foods (Wansink, Cheney, \& Chan, 2003). In the case of the soldiers, this was expressed as a physical need for meat.

In the words of Locher et al.; "Physical comfort foods are those that offer comfort either through their physical attributes or through the physical changes they bring about in the consumer" (Locher, Yoels, Maurer, \& van Ells, 2005, p. 287). In a study of food preferences, Wansink et al. (2003) found that the comfort food preferences differed across gender and age. In their study, men preferred warm, hearty, meat-related comfort foods, while women preferred comfort foods that were more snack-related. Cravings for steak, casseroles, and soup were typical for men, while women craved chocolate an ice cream. Along with other studies mentioned earlier, their study show that gender plays an important role in determining 
our food usage. Our study shows that the masculine values we identified are similar to the way men relate to (comfort) foods. Wansink et al. argue that the personal identification with a food can drive comfort food preferences (Wansink et al., 2003). This argument also seems to fit with to the characteristic food preferences among the soldiers.

The need for meat was also presented as a psychological need. One of the soldiers used the words 'mental wellbeing' about meat, and this is key to understanding the connection between welfare and wellbeing, or body and mind. Something fairly physical - chewing and swallowing a piece of meat - was transferred to a psychologically comfortable feeling. According to Locher et al. food "is much more than merely nourishment for the body; it also nourishes the mind and soul". Comfort food may help to alleviate feelings of homesickness or sadness, and can for example be used to motivate soldiers at war in a foreign country (Locher et al., 2005, p. 289). Some of the soldiers even felt the meat reduction project showed a lack of appreciation of their efforts since the project was about reducing their favourite foodstuff. The strong values associated with eating meat, as well as the disappointment provoked by MfM, demonstrate that the soldiers regarded MfM as an attack on their collective ideology.

According to Locher et al. there are four categories of comfort food: nostalgic foods, indulgence foods, convenience foods, and physical comfort foods. In a study of undergraduate students and food, they revealed that this group consumed comfort foods when they needed "an extra boost to get them through some task" (Locher et al., 2005, p. 279). Pleasure provided by food also triggered a feeling of indulgence. Just like the students in Locher et al.'s study, the soldiers relied on foods for an extra boost of pleasure. In this sense, meat did not only provide nutrition and power, but also fed the feeling of comfort. The students in Locher et al.'s study ignored concerns about health and nutrition. Although the soldiers in our study seemed very interested in the nutritional content of their food, they took little notice of the negative nutritional aspects of excessive meat consumption. The opposition between the indulgence embedded in the idea of comfort food and the health orientation characterising the situation in the camps underlines how food choices are shaped by the socio-cultural context, and bodily urge, rather than rational decisions. Although meat is not necessarily the most filling food, it is seen as indispensable because of the role it plays in the military. Meat's role as comfort food, and its associations with indulgence, pleasure, reward and physical comfort explains the soldiers' unwillingness to eat less meat.

\subsection{Limitations}

Our study was conducted among soldiers in the Norwegian Armed Forces. As national service is compulsory, presumably such a study could be representative for young Norwegians. Nevertheless, these young people are selected using strict criteria, and are a group that is particularly motivated. In other words, they might have different values and attitudes than the young people that do not meet these criteria or who abstain from the conscription selection process for other reasons. Moreover, one could claim that these young people are influenced by the institution that they are in, if not permanently then at least temporarily. This might make them more focused on consuming protein and surviving as military personnel rather than considering environmental issues such as climate change. The results of this study may have limited validity for a wider population while being applicable to the Armed Forces as an institution. Soldiers may have felt peer pressure during the focus group interviews, as the social setting might have made it difficult to present alternative viewpoints. However, the social setting of the interviews was not too far from the social setting during meals, hence a certain social pressure might characterise meal settings too. The 
predominant values the soldiers conveyed might be interconnected with a general lack of insight in food related issues, like the environmental concerns associated with meat production or health issues associated with high meat consumption. This could reflect Norwegian society at large, and might not be specific to institutions like the Norwegian Armed Forces.

\section{Conclusion}

Reducing meat consumption is important to address climate change, environmental degradation, global food security and chronic diseases (Gerber et al., 2013; Tilman \& Clark, 2014; Wellesley, Happer, \& Froggatt, 2015). Public initiatives such as MfM may guide and educate sustainable food consumption. As this study has showed, in order to be effective much more emphasis must be given to the socio-cultural factors that drive consumption. Meat equates to protein, power and comfort, and eating meat coincides with both the soldiers' mentality and the ideology projected by the military itself, since power, strength and tradition characterize both the soldiers' own identity and the military culture that they are part of. Because soldiers are expected to be strong, powerful and healthy, eating muscles to build muscles was regarded as a means to an end. Our study demonstrates how the implicit values within the military are connected to masculinity, which directs the soldiers' attitudes towards meat. Because meat is considered comfort food, the soldiers feel they have both a physical and psychological need for it. Accordingly, soldiers were sceptical to reduce meat consumption and felt that a decrease in meat consumption should be undertaken elsewhere.

Considering that the military is dominated by men, who represent the biggest consumers of meat in Norway, this study contributes to knowledge about meat and masculinity. It also provides insight into how measures to reduce meat consumption in cultures where meat has a solid position could work, or fail to do so. When such institutions choose to focus on an initiative like MfM, it is paramount that they take the time to convey the importance of their actions to the group whose diets they address. Also, the cultural and social values maintaining reluctance to reduce meat consumption must be recognized as a potential obstacle for meat reduction. Stereotypical masculine ideology is a barrier to meat reduction, and this connection should not be ignored (Rothgerber, 2013). Based on these findings, the future potential for MfM in the Norwegian Armed Forces depends on its effort to communicate why personnel ought to reduce their meat consumption, without necessarily moralizing or portraying it as another sacrifice, since the Armed Forces personnel we have interviewed feel they are already making a significant contribution to society.

\section{Acknowledgements}

We would like to thank the Co-Executive Editor Nori Geary and three anonymous reviewers for their thorough and constructive input.

We would also like to thank Commander (Navy) Pål H. Stenberg, Head of Catering Section, Material Agency, Norwegian Armed Forces for accommodating our research throughout the process and Capt (Retd) Jamie Macpherson for ensuring the use of correct English and military terminology.

\section{References}

Adams, C. (1990). The Sexual Politics of Meat. Oxford, UK: Polity Press.

Animalia. (2015). Kjøttets tilstand 2015. Retrieved from http://www.animalia.no/Kjottetstilstand/Kjottets-tilstand-2015/ 
Austgulen, M. H. (2014). Environmentally Sustainable Meat Consumption: An Analysis of the Norwegian Public Debate. Journal of Consumer Policy, 37(1), 45-66.

Bailey, R., Froggatt, A., \& Wellesley, L. (2014). Livestock - Climate Change's Forgotten Sector: Global Public Opinion on Meat and Dairy Consumption. Retrieved from Chatham House, the Royal Insititute of International Affairs: https://www.chathamhouse.org/sites/files/chathamhouse/field/field_document/201412 03LivestockClimateChangeForgottenSectorBaileyFroggattWellesleyFinal.pdf

Beardsworth, A., \& Bryman, A. (2004). Meat consumption and meat avoidance among young people: An 11 - year longitudinal study. British Food Journal, 106(4), 313-327. doi:doi:10.1108/00070700410529573

Beardsworth, A., Bryman, A., Keil, T., Goode, J., Haslam, C., \& Lancashire, E. (2002). Women, men and food: the significance of gender for nutritional attitudes and choices. British Food Journal, 104(7), 470-491. doi:doi:10.1108/00070700210418767

Bergheim, L. L., \& Stenberg, P. H. (2014). Kosthold i Forsvaret. Uten mat og drikke skapes helter ikke! Norsk Tidsskrift for Ernœring(01/14), 36-38.

Bertrand, J. T., Brown, J. E., \& Ward, V. M. (1992). Techniques for Analysing Focus Group Data. Evaluation Review, 16(2), 198-209.

Bohm, I., Lindblom, C., Åbacka, G., Bengs, C., \& Hörnell, A. (2015). "He just has to like ham" - The centrality of meat in home and consumer studies. Appetite, 95, 101-112. doi:http://dx.doi.org/10.1016/j.appet.2015.06.015

Caplan, P. (1996). Why Do People Eat What They Do? Approaches to Food and Diet from a Social Science Perspective. Clinical Child Psychology and Psychiatry, SAGE Publications, 1(2), 213-227.

Caplan, P. (1997). Food, health and identity. London: Routledge.

Dagevos, H., \& Voordouw, J. (2013). Sustainability and meat consumption: is reduction realistic? Sustainability: Science, Practice \& Policy, 9(2).

de Boer, J., Schösler, H., \& Aiking, H. (2014). “Meatless days” or “less but better”? Exploring strategies to adapt Western meat consumption to health and sustainability challenges. Appetite, 76(0), 120-128.

Difi. (2015). Offentlige anskaffelser. Retrieved from http://www.difi.no/veiledning/offentlige-anskaffelser

Douglas, M. (1984). Purity and danger : an analysis of the concepts of pollution and taboo. London: Ark Paperbacks.

Fagerli, R. A., \& Wandel, M. (1999). Gender Differences in Opinions and Practices with Regard to a "Healthy Diet">. Appetite, 32(2), 171-190. doi:http://dx.doi.org/10.1006/appe.1998.0188

Fiddes, N. (1991). Meat: a natural symbol. London: Routledge.

Forsvaret. (2013). Ernæring i felt. In T. N. D. L. Organization (Ed.). Forsvarets logistikkorganisasjon / Felleskapasiteter /Base og ABC-avdelingen/ Forpleiningsseksjonen: The Norwegian Armed Forces.

Forsvaret. (2016). Statistikk personell. Retrieved from https://forsvaret.no/aarsrapport/statistikk/personell

Friel, S., Dangour, A. D., Garnett, T., Lock, K., Chalabi, Z., Roberts, I., .. . Haines, A. (2009). Public health benefits of strategies to reduce greenhouse-gas emissions: food and agriculture. The Lancet, 374(9706), 2016-2025. doi:10.1016/S0140-6736(09)61753-0

Fuchs, D. A., \& Lorek, S. (2005). Sustainable Consumption Governance: A History of Promises and Failures. Journal of Consumer Policy, 28, 261-288.

Garnett, T. (2011). Where are the best opportunities for reducing greenhouse gas emissions in the food system (including the food chain)? Food Policy, 36, S23-S32. 
Gerber, P. J., Steinfeld, H., Henderson, B., Mottet, A., Opio, C., Dijkman, J., . . . Tempio, G. (2013). Tackling climate change through livestock - A global assessment of emissions and mitigation opportunities (978-92-5-107921-8). Retrieved from Rome: http://www.fao.org/3/a-i3437e/index.html

Graca, J., Calheiros, M. M., \& Oliveira, A. (2015). Attached to meat? (Un)Willingness and intentions to adopt a more plant-based diet. Appetite, 95, 113-125. doi:10.1016/j.appet.2015.06.024

Grønlund, A. (2015). Vurdering av klimatiltak i jordbruket (24/2015). Retrieved from

Gullestad, M. (1986). "Hverdagslivet" som symbol i norsk samtidskultur. Fortolkende analyse av ideologisk endring. Nytt norsk tidsskrift, 4.

Guzmán, M. A., \& Kjærnes, U. (1998). Menneske og dyr. En kvalitativ studie av holdninger til kjøtt. Retrieved from Oslo:

http://www.sifo.no/files/file48384_arbeidsrapport_1998-6_web.pdf

Hastrup, K. (1990). Island of anthropology : studies in past and present Iceland (Vol. vol. 5). Odense: Odense University Press.

Higgs, S. (2015). Social norms and their influence on eating behaviours. Appetite, 86, 38-44. doi:http://dx.doi.org/10.1016/j.appet.2014.10.021

Holm, L., \& Møhl, M. (2000). The role of meat in everyday food culture: an analysis of an interview study in Copenhagen. Appetite, 34(3), 277-283.

IPCC. (2014). Climate Change 2014: Mitigation of Climate Change. Contribution of Working Group III to the Fifth Assessment, Report of the Intergovernmental Panel on Climate Change. Retrieved from Cambridge, United Kingdom and New York, NY, USA: http://www.ipcc.ch/report/ar5/wg3/

Kellman, S. G. (2000). Fish, Flesh, and Foul: The Anti-Vegetarian Animus. The American Scholar, 69(4), 85-96.

Kildal, C. (2015). Introducing Sustainable Food Policies: The Case of the Norwegian Armed Forces. Master thesis. University of Oslo. Retrieved from https://www.duo.uio.no/handle/10852/45460

Kjærnes, U., Borgen, S. O., Borch, A., \& Lavik, R. (2010). Tillit til kjøtt - endringer og utfordringer i det norske markedet. Retrieved from Oslo: http://www.sifo.no/files/file77267_oppdragsrapport_14-2010_web.pdf

Kubberød, E., Ueland, Ø., Rødbotten, M., Westad, F., \& Risvik, E. (2002). Gender specific preferences and attitudes towards meat. Food Quality and Preference(13), 285-294.

Kubberød, E., Ueland, Ø., Tronstad, Å., \& Risvik, E. (2002). Attitudes towards meat and meat-eating among adolescents in Norway: a qualitative study. Appetite, 38(1), 53-62.

Lavik, R. (2008). 10 år - endring og stabilitet i forbruk og holdninger til kjøtt. 1997 - 2007. Retrieved from Oslo: http://www.sifo.no/files/file73957_oppdragsrapport_2008-2web.pdf

Le Goff, J. (1980). Time, work, \& culture in the Middle Ages. Chicago: The University of Chicago Press.

Le Goff, J., Nora, P., \& Odén, B. (1978). Att skriva historia : nya infallsvinklar och objekt. Stockholm: PAN/Norstedts.

Locher, J. L., Yoels, W. C., Maurer, D., \& van Ells, J. (2005). Comfort Foods: An Exploratory Journey Into The Social and Emotional Significance of Food. Food and Foodways, 13(4), 273-297.

Lupton, D. (1996). Food, the Body and the Self. London: SAGE Publications Ltd.

Löfgren, O. (1982). Kultur och medvetande : en tvärvetenskaplig analys. In U. Hannerz, O. Löfgren, \& R. Liljeström (Eds.). Stockholm: Akademilitteratur.

Löfgren, O. (1987). På jakt efter den borgerlige kulturen. In B. Wåhlin \& C. Kvium (Eds.), Mentalitetsforandringer : opleg fra den 19. Nordiske fagkonference i historisk 
metodelcere, Ljusterö, 31. maj-3. juni 1985 Studier i historisk metode (Vol. 19). Aarhus: Aarhus universitetsforlag.

Macdiarmid, J. I., Douglas, F., \& Campbell, J. (2016). Eating like there's no tomorrow: Public awareness of the environmental impact of food and reluctance to eat less meat as part of a sustainable diet. Appetite, 96, 487-493. doi:http://dx.doi.org/10.1016/j.appet.2015.10.011

Makiniemi, J. P., \& Vainio, A. (2014). Barriers to climate-friendly food choices among young adults in Finland. Appetite, 74, 12-19. doi:10.1016/j.appet.2013.11.016

Malterud, K. (2001). Qualitative research: standards, challenges, and guidelines. The Lancet, 358(9280), 483-488.

Monteiro, C. A., Cannon, G., Moubarac, J.-C., Martins, A. P. B., Martins, C. A., Garzillo, J., . . Jaime, P. C. (2015). Dietary guidelines to nourish humanity and the planet in the twenty-first century. A blueprint from Brazil. Public Health Nutrition, 18(13), 2311-2322. doi:10.1017/S1368980015002165

Nath, J. (2011). Gendered fare?: A qualitative investigation of alternative food and masculinities. Journal of Sociology, 47(3), 261-278. doi:10.1177/1440783310386828

Niva, M., Mäkelä, J., Kahma, N., \& Kjærnes, U. (2014). Eating Sustainably? Practices and Background Factors of Ecological Food Consumption in Four Nordic Countries. Journal of Consumer Policy, 37(4), 465-484. doi:10.1007/s10603-014-9270-4

OECD. (2016). Meat consumption. Retrieved from https://data.oecd.org/agroutput/meatconsumption.htm

Parry, J. (2010). Gender and slaughter in popular gastronomy. Feminism \& Psychology, 20(3), 381-396. doi:10.1177/0959353510368129

Pingali, P., \& McCullough, E. (2010). Drivers of Change in Global Agriculture and Livestock Systems (1022-0119). Retrieved from African Journal of Range \& Forage Science: http://dx.doi.org/10.2989/10220119.2010.529462

Roos, G., \& Wandel, M. (2004). Menn og mat. Menn, yrkedsgruppe og helselivsstil: En kvalitativ studie. Retrieved from Oslo: http://www.sifo.no/files/file48566_prosjektnotat_2004-01web.pdf

Rothgerber, H. (2013). Real Men Don't Eat (Vegetable) Quiche: Masculinity and the Justification of Meat Consumption. Psychology of Men \& Masculinity, 14(4), 363-375.

Ruby, M. B. (2012). Vegetarianism. A blossoming field of study. Appetite, 58(1), 141-150. doi:http://dx.doi.org/10.1016/j.appet.2011.09.019

Ruby, M. B., \& Heine, S. J. (2011). Meat, morals, and masculinity. Appetite, 56(2), 447-450. doi:http://dx.doi.org/10.1016/j.appet.2011.01.018

Sabaté, J., \& Soret, S. (2014). Sustainability of plant-based diets: back to the future. American Society for Nutrition, 1S-7S.

Sadalla, E., \& Burroughs, J. (1981). Profiles in eating. Sexy vegetarians and other diet-based social stereotypes. Psychology Today(15/10), 51-57.

Schösler, H., de Boer, J., Boersema, J. J., \& Aiking, H. (2015). Meat and masculinity among young Chinese, Turkish and Dutch adults in the Netherlands. Appetite, 89, 152-159. doi:http://dx.doi.org/10.1016/j.appet.2015.02.013

Setten, G. (2002). Bonden og landskapet : historier om natursyn, praksis og moral i det jærske landskapet. Geografisk institutt, Fakultet for samfunnsvitenskap og teknologiledelse, Norges teknisk-naturvitenskapelige universitet, NTNU, Trondheim.

Sobal, J. (2005). MEN, MEAT, AND MARRIAGE: MODELS OF MASCULINITY. Food and Foodways, 13(1-2), 135-158. doi:10.1080/07409710590915409

Spiller, A., \& Nitzko, S. (2015). Peak meat: the role of meat in sustainable consumption. In L. A. Reisch \& J. Thøgersen (Eds.), Handbook of Research on Sustainable Consumption. Cheltenham, UK: Edward Elgar Publishing. 
Steinfeld, H., Gerber, P., Wassenaar, T., Castel, V., Rosales, M., \& de Haan, C. (2006). Livestock's long shadow, environmental issues and options. Retrieved from

Stoll-Kleemann, S., \& Schmidt, U. J. (2016). Reducing meat consumption in developed and transition countries to counter climate change and biodiversity loss: a review of influence factors. Regional Environmental Change, 1-17. doi:10.1007/s10113-0161057-5

Syse, K. L. (2009). From land use to landscape : a cultural history of conflict and consensus in Argyll : 1945-2005. (no. 402), Faculty of Humanities, University of Oslo Unipub, Oslo.

Syse, K. L. (2017). Looking the Beast in the Eye: Re-animating Meat in Nordic and British Food Culture. In E. Lundblad (Ed.), Animalities. Literary and Cultural Studies Beyond the Human. Forthcoming 2017: Edinburgh University Press

The Norwegian Directorate of Health. (2016). Utvikling i norsk kosthold 2016. Retrieved from https://helsedirektoratet.no/Lists/Publikasjoner/Attachments/1257/Utviklingen-inorsk-kosthold-2016-IS-2558.pdf

Thorsen, L. E. (1993). Det fleksible kjønn : mentalitetsendringer i tre generasjoner bondekvinner 1920-1985. Oslo: Universitetsforl.

Tilman, D., \& Clark, M. (2014). Global diets link environmental sustainability and human health. Nature, 515(7528), 518-522. doi:10.1038/nature13959

Tobler, C., Visschers, V. H. M., \& Siegrist, M. (2011). Eating green. Consumers’ willingness to adopt ecological food consumption behaviors. Appetite, 57(3), 674-682. doi:http://dx.doi.org/10.1016/j.appet.2011.08.010

Totland, T. H., Melnæs, B. K., Lundberg-Hallen, N., Helland-Kigen, K. M., Lund-Blix, N. A., Myhre, J. B., . . . Andersen, L. F. (2012). Norkost 3. En landsomfattende kostholdsundersøkelse blant menn og kvinner i Norge i alderen 18-70 år, 2010-11. (IS-2000). Retrieved from Helsedirektoratet:

https://helsedirektoratet.no/Lists/Publikasjoner/Attachments/301/Norkost-3-enlandsomfattende-kostholdsundersokelse-blant-menn-og-kvinner-i-norge-i-alderen-1870-ar-2010-11-IS-2000.pdf

Vittersø, G., \& Rosenberg, T. G. (2014). Kjøtt og reklame. En studie av annonsering og reklame for kjøtt i det norske matmarkedet (Oppdragsrapport nr. 4). Retrieved from Oslo: http://www.sifo.no/files/file79841_oppdragsrapport_4-2014_web.pdf

Wallenborn, G., \& Wilhite, H. (2014). Rethinking embodied knowledge and household consumption. Energy Research \& Social Science, 1(0), 56-64.

Wansink, B., Cheney, M. M., \& Chan, N. (2003). Exploring comfort food preferences across age and gender. Physiology \& Behavior, 79(4-5), 739-747.

Warde, A. (2016). The practice of eating. Cambridge: Polity.

Wellesley, L., Happer, C., \& Froggatt, A. (2015). Changing Climate, Changing Diets.

Pathways to Lower Meat Consumption. Retrieved from Chatham House, the Royal Insititute of International Affairs:

https://www.chathamhouse.org/sites/files/chathamhouse/publications/research/CHHJ3 820\%20Diet\%20and\%20climate\%20change\%2018.11.15_WEB_NEW.pdf

Westhoek, H., Lesschen, J. P., Rood, T., Wagner, S., De Marco, A., Murphy-Bokern, D., .. . Oenema, O. (2014). Food choices, health and environment: Effects of cutting Europe's meat and dairy intake. Global Environmental Change, 26, 196-205. doi:http://dx.doi.org/10.1016/j.gloenvcha.2014.02.004

Williams, R. (1976). Keywords : a vocabulary of culture and society. London: Fontana/Croom Helm. 